\title{
CHANGE IN BIOCHEMICAL ACTIVITIES IN YARD LONG BEAN [VIGNA UNGUICULATA SSP. SESQUIPEDALIS (L.) VERDC] INFECTED WITH COWPEA MOSAIC VIRUS AND THEIR IMPLICATION IN DISEASE RESISTANCE
}

\author{
B LOVELY, D S RADHADEVI \& K UMAMAHESWARAN
}

Kerala Agricultural University, Vellanikkara, Thrissur, Kerala, India

\begin{abstract}
Yard long bean (Vignaunguiculata ssp. sesquipedalis(L.) Verdc.), is a distinct form of cowpea grown as a vegetable crop in southern Asia and far east, for its immature pods. Incidence of pests and diseases is considered to be a major limiting factor, affecting the production of this vegetable crop. The most important seed borne virus is the black eye cowpea mosaic virus, which is aphid transmitted. Variability in the degree of susceptibility among genotypes of yard long bean, against cowpea mosaic virus was observed. The activity of defence related enzymes peroxidase and polyphenol oxidase also exhibited a wide variation in the genotypes studied. A comparison of the vulnerability indices with their respective PAL activity, suggested the presence of a correlation between disease resistance and PAL activity of the plants. This particular trait can hence be utilised to screen, for resistance.
\end{abstract}

KEYWORDS: Yard Long Bean, Cowpea Mosaic Virus, Vulnerability Index \& Biochemical Activities

Received: Aug 11, 2017; Accepted: Aug 26, 2017; Published: Sep 02, 2017; Paper Id.: IJASROCT201713

\section{INTRODUCTION}

Incidence of pests and diseases is considered to be a major limiting factor, affecting the production of yard long bean. Many viruses are known to infect yard long bean and cause serious losses. Cowpea mosaic virus (CPMV) is a plant virus of the comovirus group. Infection of a susceptible cowpea leaf causes a "mosaic" pattern in the leaf and drastic reduction in the yield. Most of the yard long bean cultivars are susceptible to this disease. Varying degrees of resistance to this disease, among the cowpea genotypes have been reported. A heritable tendency, not to become infected when exposed to infection with a virus, to which it is susceptible, can be a very useful characteristic in a virus resistant variety. Hence, this study was intended to identify and study the sources of resistance, for developing high yielding mosaic resistant variety of yard long bean. Identification of biochemical traits of the host plant conferring to resistance to disease is also important, in breeding for disease resistance.

\section{MATERIALS AND METHODS}

The basic material for the study included 50 collections of yard long bean, from different agro climatic regions of South India. The seeds of the 50 genotypes were laid out in randomised block design, with 2 replications. In each replication, 10 plants per genotype were taken. At three-leaf stage of the crop, the individual plants were mechanically inoculated with the virus. Infected cowpea leaves were chopped and ground along with $1 \mathrm{ml} 0.1 \mathrm{M}$ phosphate buffer, at pH 7-7.5 using pestle and mortar, kept under ice cold conditions. Carborundum powder was dusted on the leaves of the plants as an abrasive. The plant extract was applied on the leaves gently, using fore finger. After 10 minutes, the leaves were washed with distilled water. The vector (Aphis craccivora) population was 
ensured for effective build up of the inoculum.

\section{Disease Incidence}

Scoring was done at 30, 45 and 60 days, after inoculation based on 0-5 scale, proposed by Rajamony et al. (1990). The disease score values recorded at 30 and 60 days, after inoculation did not exhibit much variation. Hence, the observations taken at 45 days after inoculation was only used for the assessment of degree of resistance, to black eye cowpea mosaic virus

\begin{tabular}{|c|l|}
\hline Score & \multicolumn{1}{c|}{ Symptoms } \\
\hline 0 & No symptom \\
\hline 1 & Slight vein clearing on young leaves \\
\hline 2 & Leaves with light and dark patches \\
\hline 3 & Blisters and mottling on the leaves \\
\hline 4 & Severe mottling and distortion of leaves \\
\hline 5 & Stunting of the plants with negligible or no flowering and fruiting \\
\hline
\end{tabular}

Vulnerability index was calculated as follows

$$
\mathrm{VI}=\frac{\left(0 \mathrm{n}_{0}+1 \mathrm{n}_{1}+2 \mathrm{n}_{2}+3 \mathrm{n}_{3}+4 \mathrm{n}_{4}+5 \mathrm{n}_{5}\right)}{\mathrm{n}_{\mathrm{t}}\left(\mathrm{n}_{\mathrm{c}}-1\right)}
$$

where, $\mathrm{n}_{0}, \mathrm{n}_{1}, \mathrm{n}_{2}, \mathrm{n}_{3}, \mathrm{n}_{4}$ and $\mathrm{n}_{5}$ are the number of plants in the category $0,1,2,3,4$ and 5 respectively.

$\mathrm{n}_{\mathrm{t}=}$ total number of plants; $\quad \mathrm{n}_{\mathrm{c}}=$ total number of categories

Genotypes were categorised into 5 grades, namely resistant $(0 \%)$, moderately resistant $(0-25 \%)$, moderately susceptible (26-50\%), susceptible (51-75\%) and highly susceptible (>76\%).

\section{Biochemical Traits}

The defense related enzyme activities of young leaves of ten selected genotypes with the least vulnerability indices, as well as the varieties released from the Kerala Agricultural University, were estimated.

\section{Peroxidase}

The procedure described by Srivastava (1987), was used for determining peroxidase activity. $200 \mathrm{mg}$ leaf samples were weighed and homogenised in $1 \mathrm{ml}$ of $0.1 \mathrm{M}$ sodium phosphate buffer, to which a pinch of PVP was added. The homogenisation was done at $4^{0} \mathrm{c}$. The homogenate was strained using cotton and centrifuged at $5000 \mathrm{rpm}$ for 10 minutes, at $4^{0} \mathrm{c}$. The supernatant was used as the enzyme extract for the assay of peroxidase activity. The reaction mixture, consisting of $1 \mathrm{ml}$ of $0.05 \mathrm{M}$ pyrogallol and $1 \mathrm{ml}$ of $1 \%$ hydrogen peroxide, was taken in both reference and sample cuvettes, mixed and kept in a spectrophotometer, and the reading was adjusted to zero at $420 \mathrm{~nm}$. The enzyme reaction was started by adding $50 \mu \mathrm{l}$ of enzyme extract, into sample cuvettes and change in absorbance was measured at 30 seconds interval, upto 180 seconds.

\section{Polyphenol Oxidase (PPO)}

Polyphenol oxidase activity was determined as per the procedure given by Mayer et al. (1965). The enzyme 
Change in Biochemical Activities in Yard Long Bean [Vigna Unguiculata Ssp. Sesquipedalis (L.)

Verdc.]Infected with Cowpea Mosaic Virus and their Implication in Disease Resistance

extract was prepared as per the procedure given for the estimation of peroxidase. The reaction mixture contained $1 \mathrm{ml}$ sodium phosphate buffer, $\mathrm{pH} 6.5$ and $1 \mathrm{ml}$ of $0.01 \mathrm{M}$ catechol. The cuvettes were placed in a spectrophotometer (Systronics UV - VIS spectrophotometer 118) and absorbance was set to zero. The reaction was started after adding 50 $\mu 1$ of enzyme extract. The change in absorbance was recorded at $495 \mathrm{~nm}$ and PPO activity was expressed as changes in the absorbance of the reaction mixture per $\mathrm{g}$, on fresh weight basis.

\section{Phenylalanine Ammonialyase (PAL)}

PAL activity was analysed based on the procedure described by Dickerson et al. (1984). $1 \mathrm{~g}$ of the leaf sample was weighed and homogenised in $5 \mathrm{ml}$ of $0.1 \mathrm{M}$ sodium borate buffer, to which a pinch of PVP was added. The homogenisation was done at $4^{0} \mathrm{c}$. The homogenate was centrifuged at $10,000 \mathrm{rpm}$ for $20 \mathrm{~min}$ at $4^{0} \mathrm{c}$. The supernatant was used for the assay of PAL activity. The reaction mixture contained $3 \mathrm{ml}$ of $0.1 \mathrm{M}$ sodium borate buffer ( $\mathrm{pH} 8.7$ ), $0.2 \mathrm{ml}$ enzyme extract and $0.1 \mathrm{ml}$ of $12 \mathrm{~mm}$ L-phenyl alanine, prepared in the same buffer. The blank contained $3 \mathrm{ml}$ of $0.1 \mathrm{M}$ sodium borate buffer ( $\mathrm{pH} 8.7$ ) and $0.1 \mathrm{ml}$ phenyl alanine. The reaction mixtures and blank were incubated at $40^{\circ} \mathrm{c}$, for 30 min and the reaction were stopped by adding $0.2 \mathrm{ml}$ of $3 \mathrm{~N}$ hydrochloric acid The absorbance was read at $290 \mathrm{~nm}$, in a spectrophotometer. Standard curve for transcinnamic acid was prepared, using different concentrations of cinnamic acid and PAL activity was expressed as $\mu \mathrm{g}$ of cinnamic acid produced per minute per $\mathrm{g}$, on fresh weight basis.

\section{RESULTS AND DISCUSSIONS}

The present work was undertaken to study the vulnerability of various genotypes, against cowpea mosaic virus and to determine whether the peroxidase, polyphenol oxidase and phenyl alanine ammonialyase activity changed with the susceptibility of them, towards the virus incidence.

The vulnerability index values of the 50 genotypes, along with their grades are presented in the table 1 . Among the accessions screened 21 were moderately resistant, 23 moderately susceptible, 8 susceptible and one highly susceptible to black-eye cowpea mosaic virus. The wide range of vulnerability index, among the genotypes indicates sufficient variability of resistance among the genotypes, which denotes that, there exists high scope of improvement for selection. Variability in the degree of susceptibility among genotypes of cowpea against black-eye cowpea mosaic virus, has been earlier reported by Jose et al. (2011) and Emmanuel et al. (2014). These genotypes can be utilised in breeding programme, to incorporate resistance to high yielding varieties.

Identification of biochemical traits of the host plant, conferring resistance to black-eye cowpea mosaic virus is important in breeding for disease resistance. Several defense related enzymes are found to have a correlation, with the degree of resistance possessed by the plant. The biochemical activities of the 10 genotypes with least vulnerability indices and the 3 varieties Sarika, Malika and Vaijayanthi, is presented in the table 2. The Peroxidase activity, Polyphenol oxidase activity and Phenylalanine ammonialyase activity of the young leaves, revealed wide variations There was clearly a relationship between infection and biochemical activity, with plants containing the virus exhibiting greater enzymatic activity (Nair and Umamaheswaran, 2016).

Peroxidase is one of the first enzymes responding and providing, fast defense against plant pathogens (Sulmanet al., 2001). The peroxidases are involved in the lignification, suberification and polymerisation of hydroxy-proline-rich glucoprotiens, regulation of cell wall elongation and wound healing and resistance against pathogens in plants (Yoshida et al., 2003; Makismovet al., 2014). Virus infection appears to stimulate POX activity in hosts, in which necrotic or chlorotic 
symptoms are induced, the degree of stimulation correlating with the severity of symptoms (Wood, 1990). Higher activity of POX leads to lignification process, which is considered as a resistance mechanism against pathogen attack (Anuradhaet al., 2015). Polyphenol oxidase is important in the initial stage of plant defense, where membrane damage causes release of phenols. The PPO catalyses the oxidation of phenolics to free radicals, that can react with biological molecules, thus creating an unfavourable environment for pathogen development (Mohammed et al., 2012). The total soluble phenols together with PPO, plays a role in resistance to viral pathogens (Ngadzeet al., 2012). The activity of phenylalanine ammonialyase is induced dramatically, in response to various stimuli such as tissue wounding, pathogenic attack, light, low temperature and hormones (Hahlbrock and Grisebach 1979). In plants, it is a key biosynthetic enzyme that catalyases the first step in the synthesis of a variety of polyphenol compounds (Tanaka et al., 1989) and is mainly involved in defense mechanisms. Ganapathy et al (2016) observed phenyl propanoid pathway regulation in a manner such that, the induced defense metabolites contribute to restrict pathogen invasions in the resistant genotypes.

A high activity of peroxidase and polyphenol oxidase was noted in the genotype VS 45, while the variety Vaijayanthi recorded highest Phenylalanine ammonialyase activity. Changes in peroxidase, polyphenol oxidase and phenylalanine ammonialyase activity, in leaves of resistant and susceptible cowpea genotypes were earlier reported by Sindhu (2001). A comparison of vulnerability indices of the thirteen genotypes with their respective PAL activity is depicted in Fig 1. In general, a declining trend of biochemical activities could be seen, with the increasing value of vulnerability index. This suggests the presence of a correlation between the disease resistance and the biochemical activity of the plants (Pedro et al., 2017).

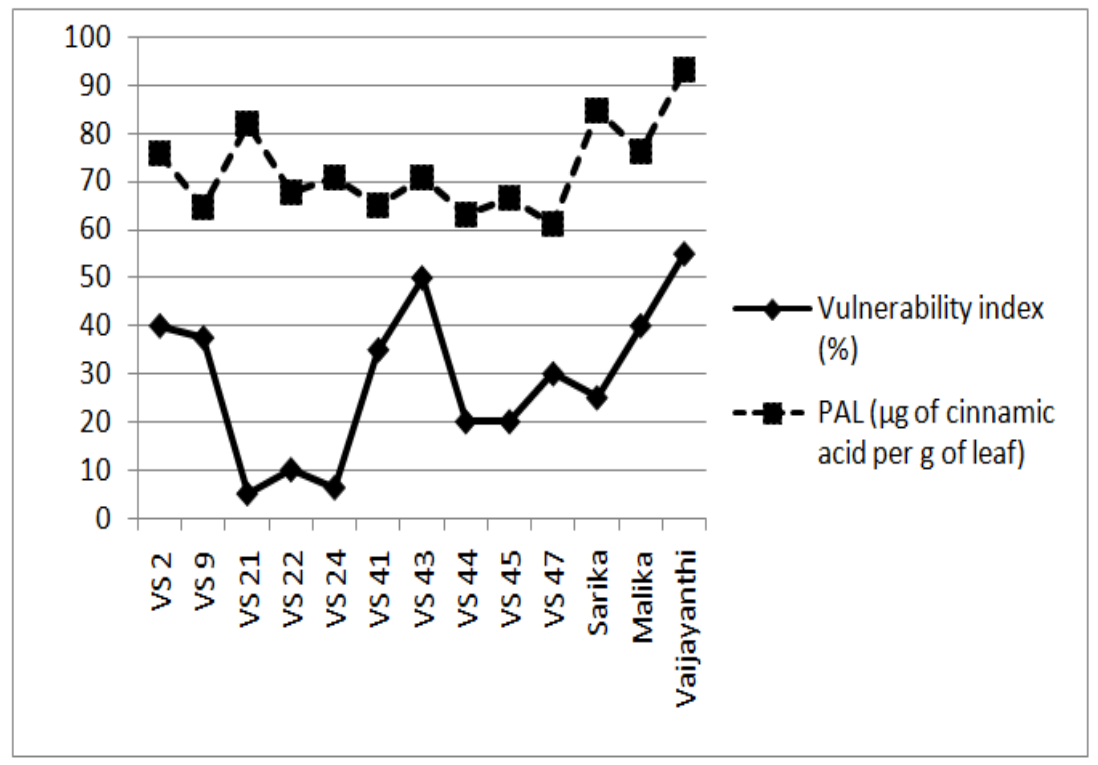

Figure 1: Comparison of Vulnerability Index with Phenylalanine Ammonialyase

\section{CONCLUSIONS}

Screening of the genotypes for resistance, under artificial incidence of black-eye cowpea mosaic virus indicated sufficient variability of resistance among the genotypes. There exists a high scope of improvement for selection. The activity of defense related enzymes namely, peroxidase, polyphenoloxidase and phenylalanine ammonialyase, exhibited a wide variation in the genotypes studied. All the biochemical parameters analyzed in cowpea leaves, showed significant 
Change in Biochemical Activities in Yard Long Bean [Vigna Unguiculata Ssp. Sesquipedalis (L.)

Verdc.]Infected with Cowpea Mosaic Virus and their Implication in Disease Resistance

changes in response to CMV infection. Early and elevated expression of defense enzymes is an important feature of plant resistance to pathogens. Our findings indicate a significant correlation between disease resistance and the biochemical activity of the infected plants. These enzymes could be considered as biochemical markers, for studying plant virus interaction in the case of Cowpea Mosaic Virus infection.

\section{ACKNOWLEDGEMENT}

The first author is grateful to Council of Scientific and Industrial Research, for granting the Junior Research Fellowship for $\mathrm{PhD}$ programme.

\section{REFERENCES}

1. Anuradha, C., Selvarajan, R., Vasantha, S. \&Suresha, G.S. (2015). Biochemical characterisation of compatible plant virus interaction: a case study with bunchy top virus-banana host-pathosystem. Plant Pathology Journal 14 (4): 212-222

2. Dickerson, D.P., Pasholati, S.F., Hagerman, A.K., Butler, L.G. \& Nicholson, R.L. (1984). Phenylalanine ammonialyasehydroxycinnamate COA ligase in maize mesocotyls inoculated with Helminthosporiummaydis or H. carbonum. Physiol. Plant Pathol. 25: 111-123

3. Emmanuel, K. M., Blasio, S.M., Phinehas, T.\&Jenipher, B.(2014). Evaluation of cowpea genotypes for virus resistance under natural conditions in Uganda. Journal of agricultural science 6(10): 176-187

4. Ganapathy, G., Keerthi, D., Nair, R.A \& Pillai, P. (2016). Correlation of Phenylalanine ammonia lyase (PAL) and Tyrosine ammonia lyase (TAL) activities to phenolics and curcuminoid content in ginger and its wild congener, Zingiber zerumbet following Pythium myriotylum infection. European Journal of Plant Pathology. 145: 777-785

5. Hahlbrock, K. \&Grisebach, H. (1979). Enzymic Controls in the Biosynthesis of Lignin and Flavonoids. Annual Review of Plant Physiology. 30 (1): 105-130

6. Jose, A.A. L., Ana, K. F. da Silva, Maria, do L. A., Nadia, R. A. F.\&Elizita, M. T.(2011).Simple and multiple resistances to viruses in cowpea genotypes. Pesq. Agropec.bras. 46(11): 1432-1438

7. Makismov, I.,Troshina, N., Surina, O. \&Cherepanova, E. (2014). Salicylic acid increases the defense reaction against bunt and smut pathogens in wheat calli. J. Plant Interact. 9: 306-314

8. Mayer, A.M. Harel, E. \&Shaul, R.B. (1965). Assay of catechol oxidase - a critical comparison of methods. Phytochemistry. 5: 783-789

9. Mohammed,H., El-Haddy, A.A. Mansour, M. \& El-Samawaty, A.E.R. (2012). Association of oxidative stress components with resistance to flax powdery mildew. TROP. Plant Pathol. 37: 386-392

10. Nair, A. B.\&Umamaheswaran, K. (2016). Enzymatic responses to Srilankan cassava mosaic virus infection in cassava plants after grafting. International Journal of Applied and Pure Science and Agriculture. 2(3)165-170

11. Ngadze, E., Icishahayo, D., Coutinho, T.A. \& Van der Waals, J.E. (2012). Role of polyphenol oxidase, peroxidase, phenylalanine ammonialyase, cholorogenic acid and total soluble phenols in resistance of potatoes to soft rot. Plant Dis. 96 : 186-192

12. Pedro, F. N. S., Fredy, D. A. S., Fabrico, E. L. C., Joaquim, A. G. S., Ilka, M. V.\& Jose, T. A. O.(2017) Photosynthetic and biochemical mechanisms of an EMS - mutagenosed cowpea associated with its resistance to cowpea severe mosaic virus. Plant Cell Rep. 36: 219-234

13. Rajamony, T., More, T.A., Seshadri, V.S. and Varma, A. (1990). Reaction of muskmelon collections to cucumber green mottle 
mosaic virus. Phytopath. 129: 237-244

14. Sindhu, A.R. (2001). Biochemical basis of resistance against black eye cowpea mosaic virus in cowpea (Vignaunguiculata (L.) Walp.). M.Sc. (Ag.) thesis. Kerala Agricultural University, Thrissur.

15. Srivastava, S.K. (1987). Peroxidase and polyphenol oxidase in Brassica juncea plants infected with Macrophominaphaseolina(Tarsi) Croid and their implication in disease resistance. Phytopath. Z. 120: 249-254

16. Sulman,M., Fox, G., Osman, A., Inkerman, A. Williams, P. \&Michalowitz, M. (2001). Rrelationship between total peroxidase activity and susceptibility to black point in mature grain of some barley cultivars. Proceedings of the $10^{\text {th }}$ Australian Barley technical Symposium, September 16-20, 2001, Canberra ACT, Australia

17. Tanaka, Y., Matsuoka, M., Yamanoto, N., Ohashi, Y., Kano-Murakami, Y. \&Ozeki, Y. (1989). Structure and characterization of a cDNA clone for phenylalanine ammonia-lyase from cut-injured roots of sweet potato. Plant Physiology. 90(4): 1403-7

18. Wood, K.R. (1990). Pathophysiological Alternations. In: Plant Viruses: Pathology, Mandahar, C.L. (Ed.) CRC Press, Boca Raton

19. Yoshida, K., Kaothien, P., Matsui, T. Kawaoka, A. \&Shinmyo, A. (2003). Molecular biology and application of plant peroxidase genes. Applied Microbiol. Biotechnol. 60: 665-670

\section{APPENDICES}

Table 1: Vulnerability Indices of the Genotypes

\begin{tabular}{|c|c|c|c|}
\hline Sl. No & Genotypes & Vulnerability Index (\%) & Grade \\
\hline 1. & VS 1 & 55 & $\mathrm{~S}$ \\
\hline 2. & VS 2 & 40 & MS \\
\hline 3. & VS 3 & 55 & $\mathrm{~S}$ \\
\hline 4. & VS 4 & 25 & MR \\
\hline 5. & VS 5 & 25 & MR \\
\hline 6. & VS 6 & 40 & MS \\
\hline 7. & VS 7 & 65.5 & $\mathrm{~S}$ \\
\hline 8. & VS 8 & 41.67 & MS \\
\hline 9. & VS 9 & 37.50 & MS \\
\hline 10. & VS 10 & 29.17 & MS \\
\hline 11. & VS 11 & 25 & MR \\
\hline 12. & VS 12 & 15 & MR \\
\hline 13. & VS 13 & 15 & MR \\
\hline 14. & VS 14 & 15 & MR \\
\hline 15. & VS 15 & 15 & MR \\
\hline 16. & VS 16 & 30 & MS \\
\hline 17. & VS 17 & 35 & MS \\
\hline 18. & VS 18 & 50 & MS \\
\hline 19. & VS 19 & 75 & $\mathrm{~S}$ \\
\hline 20. & VS 20 & 30 & MS \\
\hline 21. & VS 21 & 5 & MR \\
\hline 22. & VS 22 & 10 & MR \\
\hline 23. & VS 23 & 15 & MR \\
\hline 24. & VS 24 & 6.25 & MR \\
\hline 25. & VS 25 & 25 & MR \\
\hline 26. & VS 26 & 45 & MS \\
\hline 27. & VS 27 & 25 & MR \\
\hline 28. & VS 28 & 40 & MS \\
\hline 29. & VS 29 & 35 & MS \\
\hline 30. & VS 30 & 45 & MS \\
\hline
\end{tabular}


Change in Biochemical Activities in Yard Long Bean [Vigna Unguiculata Ssp. Sesquipedalis (L.)

\begin{tabular}{|l|c|c|l|}
\hline 31. & VS 31 & 35 & MS \\
\hline 32. & VS 32 & 30 & MS \\
\hline 33. & VS 33 & 93.75 & HS \\
\hline 34. & VS 34 & 60 & S \\
\hline 35. & VS 35 & 30 & MS \\
\hline 36. & VS 36 & 25 & MR \\
\hline 37. & VS 37 & 35 & MS \\
\hline 38. & VS 38 & 50 & MS \\
\hline 39. & VS 39 & 35 & MS \\
\hline 40. & VS 40 & 62.50 & S \\
\hline 41. & VS 41 & 35 & MS \\
\hline 42. & VS 42 & 45 & MS \\
\hline 43. & VS 43 & 50 & MS \\
\hline 44. & VS 44 & 20 & MR \\
\hline 45. & VS 45 & 20 & MR \\
\hline 46. & VS 46 & 10 & MR \\
\hline 47. & VS 47 & 30 & MS \\
\hline 48. & VS 48 & 10 & MR \\
\hline 49. & VS 49 & 10 & MR \\
\hline 50. & VS 50 & 25 & MR \\
\hline
\end{tabular}

R-Resistant; MR-Moderately resistant; MS-Moderately susceptible; S-Susceptible; HS-Highly susceptible

Table 2: Biochemical Traits of Selected Genotypes

\begin{tabular}{|c|c|c|c|c|c|}
\hline Sl. No & Genotypes & $\begin{array}{l}\text { Vulnerability } \\
\text { Index }(\%)\end{array}$ & $\begin{array}{l}\text { PO (Change in } \\
\text { Absorbance)* }\end{array}$ & $\begin{array}{c}\text { PPO (Change in } \\
\text { Absorbance)* }\end{array}$ & $\begin{array}{l}\text { PAL ( } \mu \text { g of Cinnamic } \\
\text { Acid Per } g \text { of leaf)* }\end{array}$ \\
\hline 1. & VS 2 & 40 & 0.094 & 0.0043 & 75.5 \\
\hline 2. & VS 9 & 37.50 & 0.118 & 0.0013 & 64.5 \\
\hline 3. & VS 21 & 5.00 & 0.101 & 0.0033 & 82.0 \\
\hline 4. & VS 22 & 10.00 & 0.100 & 0.0023 & 67.5 \\
\hline 5. & VS 24 & 6.25 & 0.024 & 0.0150 & 70.5 \\
\hline 6. & VS 41 & 35.0 & 0.201 & 0.0043 & 65.0 \\
\hline 7. & VS 43 & 50 & 0.150 & 0.0013 & 70.5 \\
\hline 8. & VS 44 & 20 & 0.036 & 0.0033 & 63.0 \\
\hline 9. & VS 45 & 20 & 0.209 & 0.0063 & 66.5 \\
\hline 10 & VS 47 & 30 & 0.110 & 0.0060 & 61.0 \\
\hline 11. & Sarika & 25 & 0.055 & 0.0070 & 84.5 \\
\hline 12. & Malika & 40 & 0.043 & 0.0047 & 76.0 \\
\hline 13. & Vaijayanthi & 55 & 0.126 & 0.0060 & 93.0 \\
\hline
\end{tabular}

*Values represented in the above table are mean values of duplicates 
